\title{
ON EULER-BOOLE FORMULAE
}

\author{
J. PeČArić, I. PERIĆ AND A. VuKelić
}

\begin{abstract}
A number of inequalities, for functions whose derivatives are either functions of bounded variation or Lipschitzian functions or $R$-integrable functions, is proved by applying the Euler-Boole formulae. The results are applied to obtain some error estimates for the Boole quadrature rules.
\end{abstract}

Mathematics subject classification (2000): 26D15, 26D20, 26D99.

Key words and phrases: Euler-Boole formulae, quadrature formulae, functions of bounded variation, Lipschitzian functions.

\section{REFERENCES}

[1] M. Abramowitz AND I. A. STEGUn (EDS), Handbook of mathematical functions with formulae, graphs and mathematical tables, National Bureau of Standards, Applied Math. Series 55, 4th printing, Washington, 1965.

[2] I. S. BereZin AND N. P. ZhidKov, Computing methods, Vol. I, Pergamon Press, Oxford, 1965.

[3] P. J. DaVIS AND P. RaBinOwiTZ, Methods of Numerical Integration, New York, 1975.

[4] LJ. Dedić, M. MATIĆ AND J. PEČARIĆ, On generalizations of Ostrowski inequality via some Euler-type identities, Math. Inequal. Appl., Vol. 3, No. 3 (2000), 337-353.

[5] Lj. Dedić, M. Matić And J. PeČARIĆ, Some inequalities of Euler-Grüss type, Computers and Mathematics with Applications, 41 (2001), 843-856.

[6] V. I. KRYLOV, Approximate calculation of integrals, Macmillan, New York-London, 1962.

[7] M. MATIĆ, Improvement of some inequalities of Euler-Grüs type, to appear in Computers and Mathematics with Applications. 